\title{
Underexpression of endothelial nitric oxide synthase leads to more severe pulmonary complex vascular lesions associated with HIV patients
}

\section{La baja expresión de oxido nítrico sintetasa provoca mayor severidad en las lesiones vasculares complejas asociadas al VIH}

\author{
José L. Sandoval-Gutiérrez ${ }^{1 *}$, Sharilyn Almodovar², Rosa M. Rivera-Morales ${ }^{3}$, and Juan Rodríguez-Silverio ${ }^{4}$ \\ ${ }^{1}$ Department of Pneumology, Instituto Nacional de Enfermedades Respiratorias "Ismael Cosío Villegas," Mexico City, Mexico; ${ }^{2}$ Department of \\ Immunology and Molecular Microbiology, Texas Tech University Health Sciences Center, Texas, USA; ${ }^{3}$ Department of Pathology; ${ }^{4}$ Department of \\ Pharmacology. Instituto Nacional de Enfermedades Respiratorias "Ismael Cosío Villegas", Mexico City, Mexico
}

\begin{abstract}
Background: Despite increase in survival of human immunodeficiency virus (HIV) patients due to highly active antiretroviral therapy, non-infectious complications are still prevalent such as presentation of lung vasculopathy, even in asymptomatic patients. Endothelial nitric oxide synthase (eNOS) is necessary to produce nitric oxide that causes pulmonary endothelial vasodilation. Participation of this protein in the pulmonary circulation in HIV patients has not been elucidated. This work studied the presence and expression of eNOS in pulmonary complex vascular lesions associated with HIV (PCVL/HIV). Methods: In lung tissues from patients who died from complications of HIV, we used immunohistochemistry and immune chemiluminescence (imageJ) to determine the different degrees of expression of eNOS in PCVL-HIV in comparison with nonPCVL/HIV. Reagents used were anti-eNOS and an automated system. All data are presented as mean and standard deviation. Differences were analyzed with Wilcoxon; $p<0.05$ was accepted as statistically significant. Results: In 57 tissues, the histological evidence of pulmonary vasculopathy was showed as different types (proliferative, obliterative, and plexiform) and severe presentation of vasculopathy than non-PCVL/HIV. A statistically significant decrease of eNOS was observed in all PCVL/HIV tissue samples. Conclusion: eNOS has a relevant role in the pathogenesis of pulmonary vasculopathy in acquired immunodeficiency syndrome patients. It is necessary to determine in the future the participation of eNOS and other mechanisms involved in PCVL/HIV.
\end{abstract}

Key words: Nitric oxide synthase. Human immunodeficiency virus. Pulmonary circulation.

\section{Resumen}

Antecedentes: A pesar del incremento en la sobrevivencia del paciente con virus de inmunodeficiencia humana (VIH) debido al uso del tratamiento antiretroviral altamente efectivo, las complicaciones no infecciosas siguen ocasionando vasculopatía pulmonar, aun en pacientes asintomáticos. La óxido nítrico sintetasa (ONSe) es necesaria para la producción

Correspondence:

*José Luis Sandoval Gutiérrez

E-mail: sandovalgutierrez@gmail.com
Available online: $30-01-2020$ Arch Cardiol Mex (Eng). 2020;90(1):42-47 www.archivoscardiologia.com 2604-7063 / @ 2019 Instituto Nacional de Cardiología Ignacio Chávez. Published by Permanyer. This is an open access article under the CC BY-NC-ND license (http://creativecommons.org/licenses/by-nc-nd/4.0/). 
de óxido nítrico la cual provoca vasodilatación pulmonar. La participación de esta proteína en la circulación pulmonar en los pacientes con VIH aún no se ha dilucidado. Este trabajo estudia la presencia y la expresión de ONSe en las lesiones vasculares pulmonares complejas asociadas al VIH (LVPC/VIH). Métodos: En tejidos pulmonares de pacientes que fallecieron por complicaciones del VIH, se utilizó inmunohistoquímica e inmunoquimioluminescencia (imageJ) para determinar los diferentes grados de expresión de la ONSe en LVPC/VIH. Los reactivos utilizados son anti-ONSe en sistema automatizado. Todos los datos son presentados en media y desviación estándar. Las diferencias son analizadas con la prueba de Wilcoxon; se aceptó como estadísticamente significativa una $p<0.05$. Resultados: En 57 pacientes, la histología de la vasculopatía pulmonar mostró diferentes tipos (proliferativo, obliterativo y plexiforme) además de varias presentaciones de vasculopatía en tejidos no-LVPC/VIH. Se observó diferencia estadística en la disminución de ONSe en todos los tejidos LVPC/VIH. Conclusiones: La ONSe tiene un papel relevante en la patogénesis de la vasculopatía pulmonar en el VIH. Es necesario determinar en el futuro la participación de ONSe y otros mecanismos involucrados en LVPCIVIH.

Palabras clave: Óxido nítrico sintetasa. Virus de inmunodeficiencia humana. Circulación pulmonar.

\section{Introduction}

At present, the epidemic of human immunodeficiency virus (HIV) affects more than 36.7 million people globally, with a mortality rate of 1.1 million/year ${ }^{1}$.

Many of these deaths were due to noninfectious complications like cardiovascular diseases. The first case reported of plexogenic pulmonary arteriopathy associated with HIV was carried out by autopsy?

HIV-1 infection is one of the major causes of pulmonary hypertension in the world 3 .

This infection is a risk factor for the development of pulmonary arterial hypertension (PAH), increasing up to 2000 -fold its odds 4 .

The pathogenesis for the development of endothelial vascular lesion in lung circulation like PAH associated to HIV (PAH/HIV) is still unclear.

$\mathrm{PAH} / \mathrm{HIV}$ is a devastating and life-threatening condition with recent cohort studies reporting prevalence ranging from 2.6 to $15.5 \% 5$.

The survival rate of $\mathrm{PAH} / \mathrm{HIV}$ patients is significantly reduced to one-half compared with HIV-infected individuals without $\mathrm{PAH}$.

Nitric oxide (NO) is a potent pulmonary circulation vasodilator (Fig. 1) linked to homeostatic effects in different pathologies.

$\mathrm{NO}$ is synthesized from L-arginine and oxygen through a reaction catalyzed by endothelial NO synthase $(\mathrm{eNOS})^{6,7}$.

Myriad effects of NO on pulmonary vascular cell tone such as proliferation, apoptosis, and angiogenesis have been demonstrated. Once released, it rapidly diffuses across cell membranes to reach the cytoplasm of adjacent vascular smooth muscle cells, where it binds to soluble guanylate cyclase and increases intracellular cyclic guanosine monophosphate (cGMP) levels.

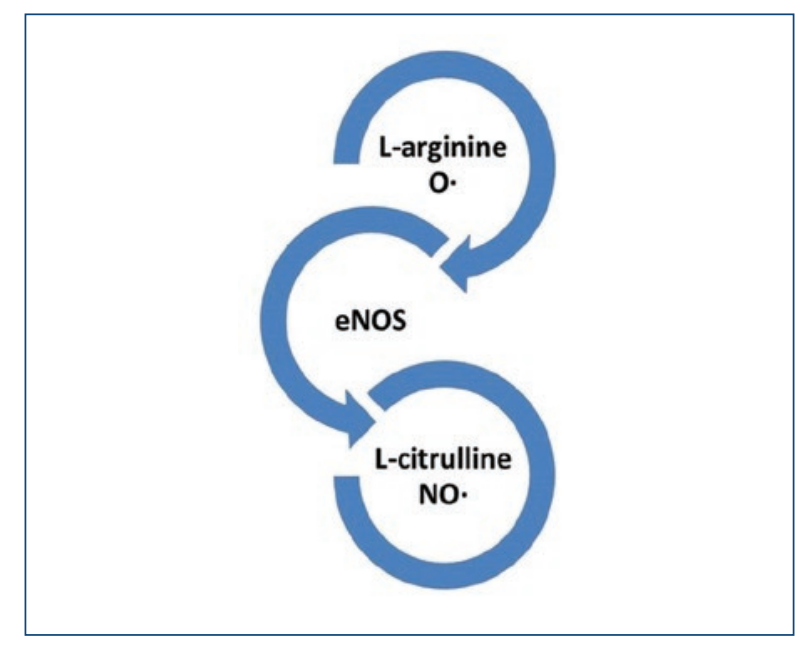

Figure 1. Synthesis of nitric oxide (NO) by endothelial nitric oxide synthetase, NO is produced when an electron from oxygen is transferred to an amino terminal nitrogen of L-arginine.

cGMP, in turn, phosphorylates cGMP-dependent protein kinase, which acts at several sites within the cell membrane and endoplasmic reticulum to lower intracellular calcium levels and reduce cross-linking of myosin light chain and decrease vascular tone ${ }^{8}$.

Asymmetric dimethylarginine (ADMA) competitively inhibits eNOS and, thus, is a mediator of endothelial dysfunction. NO inhibits endothelial apoptosis and increases vascular endothelial growth factor expression to facilitate angiogenesis.

There is no definitive proof that HIV directly causes PAH or infects pulmonary endothelial cells. Nevertheless, HIV proteins (Nef, Tat, and Env) play key roles in PAH-associated pulmonary vascular remodeling because their interactions with molecular partners in the infected cells induce inflammation, oxidative stress, and 
deregulate apoptosis and proliferation of vascular endothelial cells ${ }^{9}$.

In this work, we looked at the presence and expression of eNOS in multiple grades of pulmonary complex vascular lesions in HIV patients (PCVL/HIV) and made a comparison to non-PCVL/HIV.

\section{Methods}

\section{Tissue and histological examination}

Pulmonary tissues of patients deceased from January 2006 to December 2016 for HIV-pulmonary complications were collected during autopsies; in addition, lung tissues of HIV patients who died from acquired immunodeficiency syndrome (AIDS) with no data of PCVL (non-PCVL/HIV) cases were included in the study.

Tissues collected were formalin fixed and paraffin embedded. Lung serial sections were stained with hematoxylin and eosin (H\&E).

For this study, we used a simplified of the classical Heath and Edwards histopathology classification ${ }^{10}$ (Table 1).

\section{Immunohistochemistry and immunochemiluminescence}

Reagent used for the immunohistochemistry was the endothelial anti-NO synthase $\left(\mathrm{Abcam}^{\circledR}\right.$, ab66127, Cambridge, MA) ${ }^{11}$.

For the automated process of immunohistochemical staining, the Ventana ${ }^{\circledR}$ system (Tucson, Arizona) was used $^{12}$.

The eNOS quantification was measured by chemiluminescence on slides stained with $\mathrm{H} \& \mathrm{E}$ first and processed by the image processing software named ImageJ, download free provided by the National Institutes of Health of the United States ${ }^{13}$.

The expression of the protein was measured in pixel units (arbitrary units).

\section{Ethics}

This work had the authorization of the Ethics and Research Committee of the National Institute of Respiratory Diseases (B-19-13).

\section{Statistics}

All the data are presented as mean and standard deviation (SD), the differences were analyzed with
Table 1. Heath and Edwards pulmonary circulation simplified pathology classification

\section{Severity Grades}

Grade I: Hypertrophy of the media of small arteries and arterioles and proliferation of the intima

Grade II: Thickening of the middle layer with hypertrophy and hyperplasia, showing plexiform lesions in the muscle

Grade III: Injury and cavernous angioma, with intimal hyalinization, fibrosis, and/or necrotizing artery

Table 2. Summary of demographic and disease characteristics HIV/AIDS study group

\begin{tabular}{|c|c|}
\hline $\mathrm{n}$ & 57 \\
\hline Mean age, years (range) & 38.3 years \pm 2.12 years $(22-60)$ \\
\hline Male (\%) & 88 \\
\hline $\begin{array}{l}\text { HIV risk factor }(\%) \\
\text { Intravenous drug use } \\
\text { Homosexual } \\
\text { Heterosexual }\end{array}$ & $\begin{array}{c}1 \\
41 \\
15\end{array}$ \\
\hline $\begin{array}{l}\text { Pulmonary coinfections } \\
\text { PCP } \\
\text { Polymicrobial } \\
\text { CMV } \\
\text { Histoplasma sp. } \\
\text { MTB }\end{array}$ & $\begin{array}{c}21 \\
16 \\
10 \\
6 \\
4\end{array}$ \\
\hline 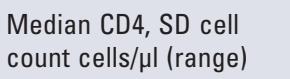 & $36 \pm 3$ cells $(1-115)$ \\
\hline $\begin{array}{l}\text { Viral load count, } \\
\text { SD (range) }\end{array}$ & $355,000 \pm 165,000(150,000-1$ million \\
\hline $\begin{array}{l}\text { Median follow-up, } \\
\text { years (range) }\end{array}$ & $3.0 \pm 2.3(0-9)$ \\
\hline \multicolumn{2}{|c|}{$\begin{array}{l}\text { HAART } \\
37 \text { used before hospitalization } \\
10 \text { initiated at or after HIV diagnosis in hospital } \\
10 \text { never received }\end{array}$} \\
\hline
\end{tabular}

PCP: Pneumocystis jiroveci; CMV: Cytomegalovirus; MTB: Mycobacterium tuberculosis; HAART: highly active antiretroviral therapy; AIDS: acquired immunodeficiency syndrome; HIV: human immunodeficiency virus; SD: standard deviation

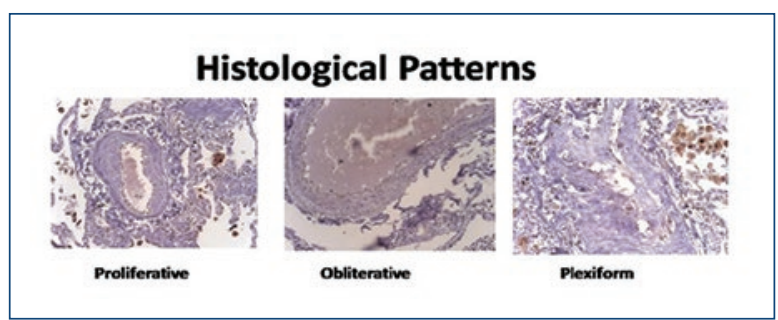

Figure 2. Examples of the most representative pulmonary circulation lesions in autopsy material of acquired immunodeficiency syndrome patients (hematoxylin and eosin staining). 


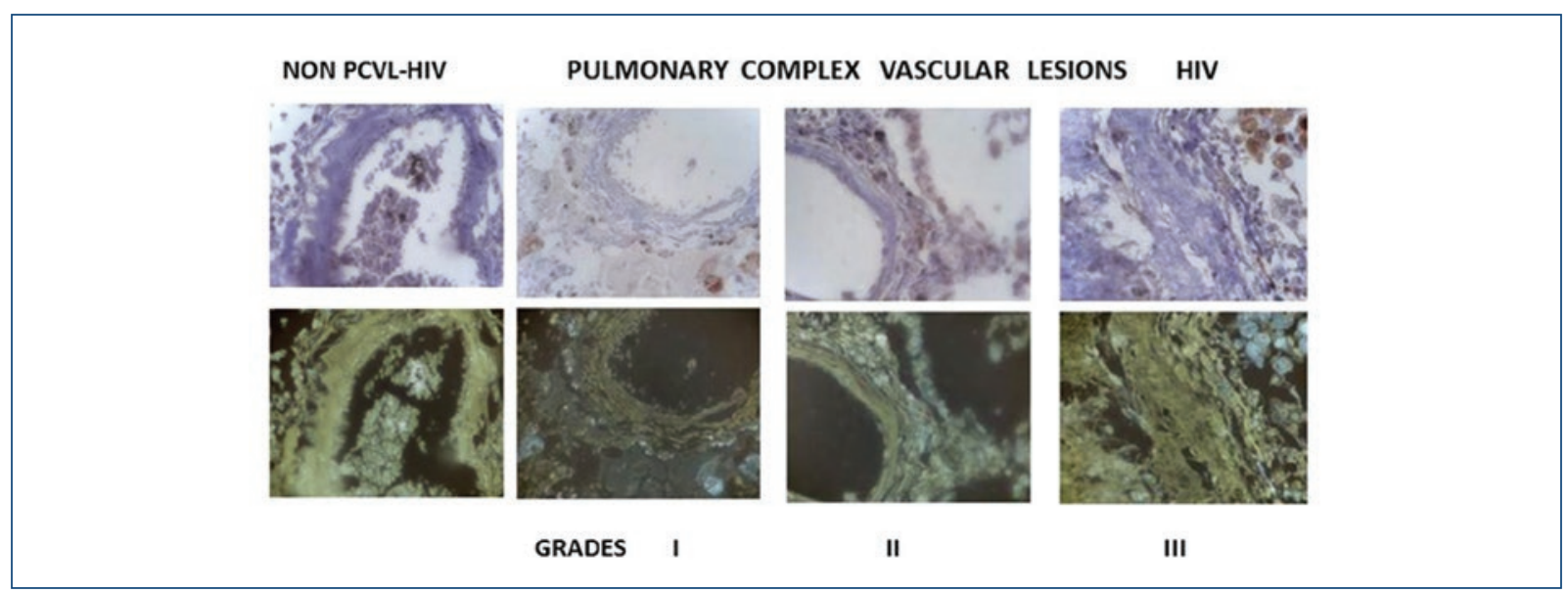

Figure 3. Seen at the top left by immunohistochemical nitric oxide synthetase staining (brown) in non-pulmonary complex vascular lesions (PCVL)-human immunodeficiency virus (HIV) lesions (all Grade III) and the different PCVL-HIV degrees (I-III).

At the bottom, the tissues are subjected to the image processor (imageJ) observed the expression of endothelial nitric oxide synthetase (gray).

*Non-PCVL-HIV: non-pulmonary complex vascular lesion in HIV patients.

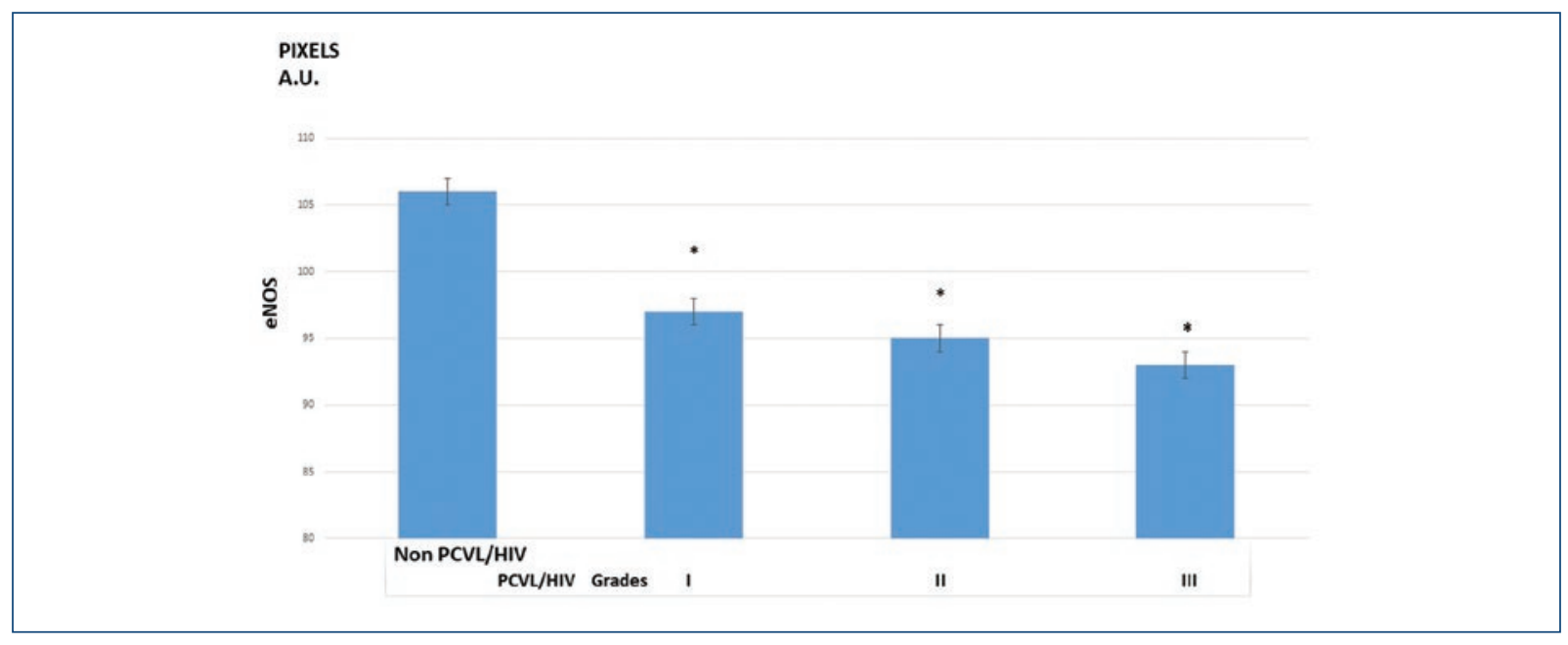

Figure 4. Difference in the expression of endothelial nitric oxide synthetase is observed in the intragroup different degrees of pulmonary complex vascular lesions/human immunodeficiency virus (PCVL/HIV) and with regard to the non-PCVL/HIV.

A.U.: arbitrary units.

${ }^{*} \mathrm{p}<0.05$ Wilcoxon test.

non-parametric Wilcoxon rank-sum test, two samples; $p<0.05$ was accepted as statistically significant, the Statistical Package for the Social Sciences (SPSS ${ }^{\circledR}$ version 20) was used.

\section{Results}

Lung tissues from a total a 57 subjects with HIV (52 men) with an average age of 38.3 years (SD 2.12). All patients were in AIDS (Stage C3) according to the classification of the Center for Disease Control and Prevention (CDC) in Atlanta, GA, USA.

The cause of death was mainly pulmonary complications (Table 2).

Lung tissues were paraffin embedded and H\&E stained and processed for immunohistochemistry and were examined microscopically by an experienced pathologist in pulmonary circulation (M.R.R.R.) who 
determined that $30 / 57$ tissues (55\%) showed PCVL with histological evidence of pulmonary vasculopathy or different types: proliferative (60\%), plexiform (25\%), and obliterative pattern (15\%) (Fig. 2).

PCVL/HIV histological presentation: eight cases in Grade I, 7 in Grade II, and 15 in Grade III. eNOS imagej chemiluminescence showed a marked decrease expression associated with the severity of the lesion: nonPCVL/HIV group (17 lung tissues) had 106 pixels (SD 5.10) and PCVL/HIV group: 97 pixels (SD3.20) in Grade I, 95 pixels (SD 3.94) in Grade II, and 93 pixels (SD 3.70) in Grade III, statistical analysis of the Wilcoxon test showed significance $(p<0.05)$ among the four groups.

The statistical analysis of the Wilcoxon test showed significance $(p<0.05)$ after comparison of the intensity of Grade I compared with Grade II, and of this compared to Grade III, showing lower expression of eNOS to increased severity of PCVL (Fig. 3)

In all measurements of eNOS chemiluminescence in PCVL/HIV have significant diminution than in comparison with the caused by non-PCVL/HIV (Fig. 4).

\section{Discussion}

Infection with HIV infection induces a chronic inflammatory state and persistent immune activation and dysregulation that could indirectly induce the release of pro-inflammatory cytokines and growth factors that may be implicated in the pathogenesis of pulmonary vasculopathy.

These features include concentric laminar intimal fibrosis, medial hypertrophy, recanalized thrombi, and plexiform lesions. Additional hallmarks include increased expression of smooth muscle cell/fibroblast growth factors such as platelet-derived growth factor; inflammatory cells are present in the perivascular of HIV tissues, suggesting that HIV-induced chronic inflammation and immune hyperactivation may enrich the pro-inflammatory milieu implicated in vascular lesions.

Endothelial injury has been proposed to be a critical step in the initiation and progression of vascular remodeling associated with $\mathrm{PAH}^{14}$.

Endothelial alterations precede the development of muscularization of pulmonary arteries in animal models $^{15}$.

It has been considered to the PCVL-HIV as a process of dysfunction of the vascular endothelium where you can engage different mechanisms such as the accessory proteins of HIV (Nef, Tat, and Env) ${ }^{16}$ in the inactivation of $\mathrm{NO}$ conditioned by alterations in the role of
eNOS. The exact role that NO plays in the pathophysiology of PAH is still unclear. Numerous studies have demonstrated that pulmonary hemodynamics and functional capacity can be improved in these patients by increasing NO delivery to the lung ${ }^{17-19}$.

Our study is limited by the lack of hemodynamic data before death for a conclusive diagnosis of $\mathrm{PAH}$, due to the lack of clinical suspicion by the treatment group (internal medicine, infectious diseases, and pulmonologist specialist) for the request of an echocardiogram in addition to the impossibility of performing right cardiac catheterization in a patient with severe sepsis.

Pharmacologic therapies that target the NO/cGMP pathway represent one of the major approaches to medical management or the patient with $\mathrm{PAH}^{20,21}$.

Increase levels of ADMA are independently associated with HAP-HIV, the ADMA-NO axis is an important mechanism to be studied in the future ${ }^{22}$.

In non-human primates as animal models like macaques the infection with Simian immunodeficiency virus/nef recombinant virus demonstrated pulmonary vascular remodeling without lesions were found in outside lung organs, suggesting a pulmonary-specific target ${ }^{23}$.

Numerous pieces of the NO synthesis and signaling pathways are disrupted or altered in pulmonary vascular diseases. Although the data implicating NO deficiency in the pathogenesis of PAH are compelling, it is unclear which part of the biosynthesis pathway is impaired.

Evidence is accumulating that modification of deficiencies in NO synthesis and/or enhancement of its downstream signaling targets can attenuate pulmonary vascular remodeling.

Despite the increase in survival of HIV patients as a result of highly active antiretroviral therapy, pulmonary complications are still prevalent in the presentation of pulmonary vasculopathy even in asymptomatic patients. The accurate clinical diagnosis in the initial phase of the disease is necessary to improve the prognosis and survival.

These results show the preponderant reduce the presence of eNOS in pulmonary vasculopathy in AIDS patients. To the best of our knowledge, this is the first work that shows the significant diminution of eNOS in PCVL/HIV compared to non-PCVL/HIV.

It is important to continue the study in the future of $\mathrm{NO}$ and the inflammatory mechanism of the retroviruses on the pulmonary circulation, to promote a biological marker to detect PAH-HIV in asymptomatic patients and guide the therapy in the initial stages of this pathology 24,25 . 


\section{Funding}

Instituto Nacional de Enfermedades Respiratorias "Ismael Cosío Villegas".

\section{Conflicts of interest}

The are no conflicts of interest.

\section{Ethical responsibilities}

Protection of human and animal subjects. The authors declare that no experiments were performed on humans or animals for this study.

Confidentiality of data. The authors declare that no patient data appear in this article.

Right to privacy and informed consent. The authors declare that no patient data appear in this article.

\section{References}

1. HIV/AIDS Data and Statistics. Available from: http://www.who.int/hiv/data/ en. [Last accessed on 2019 May 05].

2. Kim KK, Factor SM. Membranoproliferative glomerulonephritis and plexogenic pulmonary arteriopathy in a homosexual man with acquired immunodeficiency syndrome. Hum Pathol. 1987;18:1293-6.

3. Cicalini S, Almodovar S, Grilli E, Flores S. Pulmonary hypertension and human immunodeficiency virus infection: epidemiology, pathogenesis, and clinical approach. Clin Microbiol Infect. 2011;17:25-33.

4. Araújo I, Enjuanes-Grau C, Lopez-Guarch CJ, Narankiewicz D, Ruiz-Cano MJ, Velazquez-Martin T, et al. Pulmonary arterial hypertension related to human immunodeficiency virus infection: a case series. World J Cardiol. 2014;6:495-501.

5. Jarrett H, Barnett C. HIV-associated pulmonary hypertension. Curr Opin HIV AIDS. 2017;12:566-71.

6. Klinger JR, Abman SH, Gladwin MT. Nitric oxide deficiency and endothelial dysfunction in pulmonary arterial hypertension. Am J Respir Crit Care Med. 2013;188:639-46.

7. Klinger JR. The nitric oxide/cGMP signaling pathway in pulmonary hypertension. Clin Chest Med. 2007;28:143-67, 9.
8. Chinnappan M, Mohan A, Agarwal S, Dalvi P, Dhillon NK. Network of microRNAs mediate translational repression of bone morphogenetic protein receptor-2: involvement in HIV-associated pulmonary vascular remodeling. J Am Heart Assoc. 2018;7:e008472.

9. Dalvi P, Sharma H, Chinnappan M, Sanderson M, Allen J, Zeng R, et al. Enhanced autophagy in pulmonary endothelial cells on exposure to HIVtat and morphine: role in HIV-related pulmonary arterial hypertension. Autophagy. 2016;12:2420-38.

10. Heath D, Edwards JE. The pathology of hypertensive pulmonary vascular disease; a description of six grades of structural changes in the pulmonary arteries with special reference to congenital cardiac septal defects. Circulation. 1958;18:533-47.

11. Available from: http://www.abcam.com/enos-antibody-ab66127.html. [Last accesed on 2019 May 06].

12. Available from: http://www.ventana.com. [Last accesed on 2018 Oct 20

13. Available from: $h$ ttp://www.rsbweb.nih.gov/ij. [Last accessed on 2018 Oct 25.

14. Sakao S, Taraseviciene-Stewart L, Lee JD, Wood K, Cool CD, Voelkel NF, et al. Initial apoptosis is followed by increased proliferation of apoptosis-resistant endothelial cells. FASEB J. 2005;19:1178-80.

15. Rosenberg HC, Rabinovitch M. Endothelial injury and vascular reactivity in monocrotaline pulmonary hypertension. Am JPhysiol. 1988:255:H1484-91.

16. Voelkel NF, Cool CD, Flores S. From viral infection to pulmonary arterial hypertension: a role for viral proteins? AIDS. 2008;22 Suppl 3:S49-53.

17. Ghosh S, Gupta M, Xu W, Mavrakis DA, Janocha AJ, Comhair SA, et al. Phosphorylation inactivation of endothelial nitric oxide synthesis in pulmonary arterial hypertension. Am J Physiol Lung Cell Mol Physiol. 2016;310:L1199-205.

18. Zou L, Xu X, Zhai Z, Yang T, Jin J, Xiao F, et al. Identification of downstream target genes regulated by the nitric oxide-soluble guanylate cyclase-cyclic guanosine monophosphate signal pathway in pulmonary hypertension. J Int Med Res. 2016;44:508-19.

19. Gao Y, Chen T, Raj JU. Endothelial and smooth muscle cell interactions in the pathobiology of pulmonary hypertension. Am J Respir Cell Mol Biol. 2016;54:451-60.

20. Pulido T, Zayas N, de Mendieta MA, Plascencia K, Escobar J. Medical therapies for pulmonary arterial hypertension. Heart Fail Rev. 2016;21:273-83.

21. Mohamed NA, Ahmetaj-Shala B, Duluc L, Mackenzie LS, Kirkby NS, Reed $\mathrm{DM}$, et al. A new NO-releasing nanoformulation for the treatment of pulmonary arterial hypertension. J Cardiovasc Transl Res. 2016;9:162-4.

22. Parikh RV, Scherzer R, Nitta EM, Leone A, Hur S, Mistry V, et al. Increased levels of asymmetric dimethylarginine are associated with pulmonary arterial hypertension in HIV infection. AIDS. 2014;28:511-9.

23. Almodovar S, Swanson J, Giavedoni LD, Kanthaswamy S, Long CS, Voelkel NF, et al. Lung vascular remodeling, cardiac hypertrophy, and inflammatory cytokines in SHIVnef-infected macaques. Viral Immunol. 2018;31:206-22.

24. Almodovar S, Hsue PY, Morelli J, Huang L, Flores SC, Lung HIV Study, et al. Pathogenesis of HIV-associated pulmonary hypertension: potential role of HIV-1 nef. Proc Am Thorac Soc. 2011;8:308-12

25. Sandoval-Gutierrez JL, Rodriguez-Silverio J, Rivera-Rosales RM, Sevilla-Reyes E, Flores-Murrieta FJ, Rojas-Serrano J, et al. Overexpression of endothelin-1 leads to more severe pulmonary complex vascular lesions associated with the human immunodeficiency virus. Arch Med Res. 2015;46:228-32. 